\title{
MENINGKATKAN KEMAMPUAN DAN KREATIVITAS SISWA DALAM MEMAINKAN MUSIK TRADISIONAL MELALUI METODE TUTOR SEBAYA
}

\author{
Dedi Kurniadi \\ SMP Negeri 1 Sukaresmi Cianjur \\ E-mail: dedkur569@gmail.com
}

\begin{abstract}
Abstrak
Penelitian Tindakan Kelas ini dilaksanakan di Kelas VIII A SMPN I Sukaresmi dalam upaya meningkatkan kemampuan dan kreativitas siswa dalam memainkan musik tradisional. Dengan melihat hasil belajar siswa yang masih dibawah nilai Kriteria Ketuntasan Minimal (77), maka peneliti merasa perlu mengadakan penelitian. Metode Penelitian Tindakan Kelas ini diawali dengan perencanaan tindakan, pelaksanaan tindakan, observasi dan refleksi. Kegiatan ini dilaksanakan sebanyak dua kali, yaitu pada siklus I dan siklus II, dengan tujuan untuk meningkatkan kemampuan dan kreatifitas siswa dalam memainkan musik tradisional yang merupakan akar permasalahannya. Pada hasil penelitian, terbukti adanya peningkatan dalam kreativitas memainkan musik tradisional yang dimiliki siswa melalui pembelajaran dengan menggunakan metode tutor sebaya. Hal ini dapat dilihat dari hasil penilaian Seni Budaya khususnya Musik Tradisional pada Siklus I dan Siklus II. Siswa yang memperoleh nilai dibawah KKM pada Pra Penelitian sebanyak 24 orang $(63,16 \%)$, pada Siklus I berkurang menjadi 13 orang $(34,21 \%)$ berarti naik sekitar $29 \%$ dari sebelumnya, dan setelah pelaksanaan tindakan kelas pada Siklus II seluruh siswa yaitu 38 orang (100\%) mencapai nilai KKM $(77,00)$ tidak ada lagi siswa dengan nilai dibawah KKM $(0 \%)$. Sedangkan nilai ratarata yang diperoleh siswa adalah 72,03 pada Pra Siklus, 77,05 pada Siklus I dan pada Siklus II 80,55. Penggunaan Metode Tutor Sebaya dalam seni musik tradisional ini sangat efektif dan cukup menyenangkan serta tidak membosankan. Berdasarkan angket respon siswa setelah belajar dengan menggunakan metode tutor sebaya ini, data kuantitatif dan kualitatif membuktikan $90 \%$ siswa menyatakan senang, 10\% siswa masih merasa kesulitan dengan metode pembelajaran ini. Dari uraian di atas, peneliti menyimpulkan bahwa penggunaan metode tutor sebaya dalam seni musik tradisional dapat meningkatkan kemampuan siswa dalam kreativitas memainkan musik tradisional, oleh karena itu peneliti menyarankan untuk menggunakannya sebagai alternatif dalam pembelajaran Seni Budaya Khususnya Seni Musik Tradisional Nusantara.
\end{abstract}

Kata kunci: tutor sebaya, kreativitas, musik tradisional

\section{IMPROVING STUDENTS' ABILITY AND CREATIVITY IN PLAYING TRADITIONAL MUSIC THROUGH PEER TUTORIAL METHOD}

\begin{abstract}
This Classroom Action Research was carried out in Class VIII A of SMPN 1 Sukaresmi as an effort to improve students' ability and creativity in playing traditional music. By looking at student learning outcomes that are still below the Minimum Completeness Criteria (77), the researchers need to conduct Classroom action research. It begins with action planning, action execution, observation and reflection. This activity was carried out twice in cycle I and cycle II, with the aim to improving the ability and creativity of students in playing traditional music which is the root of the problem.In the results of the study, it was proven that there was an increase in creativity in playing traditional music owned by students through learning using peer tutorial method. This
\end{abstract}


can be seen from the results of the assessment of Cultural Arts, especially Traditional Music in Cycle I and Cycle II. Students who scored under the Minimum Completeness Criteria in PreResearch were 24 people $(63.16 \%)$, in Cycle I it was reduced to 13 people (34.21\%), it means there was an increase about $29 \%$ than before, and after the class action in Cycle II all students were 38 people $(100 \%)$ reached the minimum completeness criteria (77.00) there were no more students with a score below the minimum completeness criteria $(0 \%)$. While the average score obtained by students was 72.03 in the Pre-Cycle, 77.05 in Cycle I and in Cycle II 80.55. Using Peer Tutorial Method in traditional music art is very effective and quite fun and not boring. Based on the student response questionnaire after learning using this peer tutorial method, it was proven and $90 \%$ of students expressed pleasure, $10 \%$ of students still felt difficulties with this learning method.From the description above, the researcher concludes that the use of peer tutorial method in the traditional music art can improve students' ability and creativity to play traditional music, therefore researchers recommend using peer tutorial method as an alternative in learning the Cultural Arts, especially the Traditional Music of the Archipelago

Keywords: peer tutorial method, ability and creativity, traditional music

\section{PENDAHULUAN}

Pembelajaran seni musik adalah pembelajaran seni budaya yang berusaha menggali serta mengembangkan potensi estetika peserta didik serta mempengaruhi siswa agar mempunyai nilai estetika sehingga dapat memperhalus budi pekerti karena dalam seni terdapat unsur-unsur keindahan, keteraturan, kedisiplinan, dan dinamika. Melalui pendekatan "belajar dengan seni," "belajar melalui seni", dan "belajar tentang seni", pembelajaran senimusik diberikan karena keunikan, kebermaknaan, dan kebermanfaatan terhadap perkembangan peserta didik berupa pemberian pengalaman estetik dalam bentuk kegiatan berekspresi / berkreasi. Oleh sebab itu apabila setelah belajar peserta didik tidak ada perubahan tingkah laku yang positif dalam arti tidak memiliki kecakapan baru serta wawasan pengetahuannya tidak bertambah, maka dapat dikatakan bahwa belajarnya belum sempurna.

Pendidikan seni musik di SMP/MTs saat ini semakin berkembang pesat, sehingga sebagai calon maupun tenaga pendidik perlu mencari model-model pembelajaran yang inovatif untuk lebih meningkatkan kualitas output peserta didiknya seperti dalam UndangUndang Sistem Pendidikan Nasional No. 20 pasal 3 Tahun 2003, Undang-Undang RI No. 12 tahun 2005 dan Peraturan Pemerintah Nomor
19 Tahun 2005 yang mengamanatkan bahwa guru wajib memiliki kualifikasi akademik, kompetensi, sertifikat pendidik, sehat jasmani dan rohani, serta memiliki kemampuan untuk mewujudkan tujuan pendidikan nasional. Sejalan dengan kebijakan Otonomi pendidikan dengan penerapan Kurikulum Tingkat Satuan Pendidikan(KTSP)di SMPNegeri 1 Sukaresmi, berdampak pada penyediaan fasilitas sarana dan prasarana belajar yang sudah representatif berupa ruang musik sekaligus peralatan musik Tradisional yang sudah lengkap, baik instrument alat musik maupun sound system, maka pembelajaran seni musik diharapkan mampumemberikan pemahaman, pengetahuan, pengalaman, juga kemampuan berkarya seni agar siswa bisa berapresiasi terhadap budaya sendiri dan bisa menghargai orang lain yang pada akhirnya mereka bisa berperan aktif dalam kehidupan bermasyarakat, berbangsa dan bernegara. Keberlangsungan pembelajaran seni budaya juga sudah dioptimalkan dengan melayani kebutuhan hakiki berkesenian sesuai bakat dan minat siswa dengan menerapkan model pembelajaran tutor sebaya sehingga dapat meningkatkan hasil pembelajaran seni musik yang optimal.

Ketersediaan fasilitas yang representatif di sekolah tidak serta merta dengan mudah bisa dimanfaatkan oleh peserta didik secara optimal 
untuk mengembangkan kemampuan apresiasi dan kreativitas bermain musik. Kenyataan di lapangan kemampuan belajar seni musik tradisional siswa di kelas VIII A yang berjumlah 38 orang sampai saat ini hampir $63 \%$ masih dibawah KKM, yang mendapat nilai dibawah KKM sebanyak 24 orang $(63,16 \%)$ dan yang mendapat nilai diatas KKM sebanyak 15 orang $(36,84 \%)$. Adapun nilai KKM seni musik adalah 77,00. Beberapa faktor penyebab rendahnya kemampuan dan kreativitas siswa dalam memainkan musik tradisional antara lain:

a) perbedaan rentang nilai yang menyolok antara siswa yang skill/talenta musikalnya bagus dengan siswa yang kurang cakap;

b) munculnya sikap egois siswa pandai yang merasa tinggi hati dan enggan berbagi kecakapan dengan temannya yang belum menguasai alat music secara baik;

c) rendahnya motivasi berlatih musik bagi sebagian siswa terutama disebabkan terbatasnya mendapat bimbingan yang memadai;

d) keterbatasan daya pemantauan guru kepada siswa dalam penugasan latihan musik di luar sekolah juga berdampak lambatnya mengasah skill siswa.

Apalagi dalam permainan musik tradisional yang terbatas pada grup/kelompok kecil menuntut skill masing-masing pemusik dalam membawakan suatu karya musik. Sementara alokasi waktu tatap muka yang tersedia belum bisa secara maksimal menghasilkan kualitas pembelajaran yang optimal.

Di sisi lain, tak bisa dipungkiri bahwa teramat jarang ditemukan guru seni yang memiliki multi talenta dalam kecakapan menguasai permainan seluruh ragam alat musik. Sehingga praktis guru hanya mampu memberikan dasar-dasar bermain musik untuk beberapa jenis alat musik tertentu saja.

Berdasarkan paparan adanya kesenjangan untuk tuntutan pembelajaran kooperatif berupa bermain musik bersama yang disebabkan masih banyak hambatan belajar oleh faktor eksternal, maka diusulkan solusi yang berkaitan dengan strategi pembelajaran.
Adapun metode pembelajaran yang sesuai untuk mengatasi permasalahan tersebut adalah metode pembelajaran tutor sebaya. Metode pembelajaran dengan mengandalkan kemampuan teman sebaya sebagai tutor/ pembimbing dalam praktik bermain musik tradisional ini dipilih mengingat ada beberapa siswa yang sudah memiliki kecakapan bermain musik seperti boning, penerus, jengglong, goong. Hasil yang diharapkan, siswa dapat belajar bersama, saling menyumbangkan pikiran dan bertanggung jawab terhadap pencapaian hasil belajar secara individu maupun kelompok. Terutama pada materi pembelajaran dengan kompetensi menyajikan musik bersama dari karya musik Nusantara berdasarkan pengembangan gagasan kreatif dalam bentuk musik tradisional yang menuntut skill musical seseorang harus bisa menyesuaikan dengan pemain lain. Siswa harus menjaga atau menciptakan harmonisasi dari musik yang mereka mainkan. Dengan bermain musik di sebuah group atau kelompok, siswa dapat belajar bagaimana menyatukan rasa hati \& visi, melatih kesabaran, keuletan, belajar menghargai ide atau pendapat orang lain, belajar disiplin, belajar bersosialisasi dan banyak lagi sisi edukasi positif

Berdasarkan uraian di atas, penulis tertarik untuk melakukan penelitian tindakan kelas dengan judul meningkatkan Kemampuan dan Kreativitas Siswa dalam Memainkan Musik Tradisional Melalui Metode Tutor Sebaya.

\section{METODE}

Penelitian ini menggunakan metode penelitian tindakan kelas (PTK). Hal ini disesuaikan dengan karakteristik penelitian tindakan kelas yaitu masalah penelitian yang harus dipecahkan berasal dari persoalan praktik pembelajaran di kelas atau berangkat dari permasalahan praktik faktual. Model penelitian tindakan kelas ini merujuk pada model Kemmis \& MC Taggart yang menguraikan bahwa tindakan yang digambarkan sebagai suatu proses yang dinamis dari aspek perencanaan, tindakan, observasi dan refleksi. Dikemukakan oleh Harjodipuro (1997), seperti yang dikutip 
oleh Muslihudin (2008:7), bahwa yang dimaksud dengan Penelitian Tindakan Kelas adalah "Suatu pendekatan untuk memperbaiki pendidikan melalui perubahan, dengan mendorong para guru untuk memikirkan praktik mengajarnya sendiri, agar kritis terhadap praktik tersebut dan agar mau untuk mengubahnya ."

Menurut John Elliot (1982), juga dikutip oleh Muslihuddin (2008:6) bahwa yang dimaksud dengan PTK adalah "Kajian tentang situasi sosial dengan maksud untuk meningkatkan kualitas tindakan didalamnya. Seluruh proses, telaah diagnosis, perencanaan, pelaksanaan, pemantauan dan pengaruh menciptakan hubungan yang diperlukan antara evaluasi diri dan perkembangan propesional."

Subyek penelitian dalam PTK ini adalah siswa kelas VIII A di SMP Negeri 1 Sukaresmi semester genap tahun pelajaran 2014/2015. Materi yang diajarkan adalah Standar Kompetensi 12 yaitu Mengekspresikan karya seni musik Nusantara dengan Kompetensi Dasar 12.3 Menyajikan karya seni musik tradisional Nusantara secara perseorangan dan berkelompok di kelas atau sekolah. Indikator pembelajarannya adalah membuat perencanaan pementasan di dalam kelas, dan menyajikan karya serta berdasarkan pengembangan gagasan kreatif secara kelompok. Spesifikasi kelas VIII A yang dipilih dalam penelitian ini terdiri dari siswa-siswi peserta seni musik kelas VIII A yang berjumlah 38 siswa (19 putra dan 19 putri). Karakteristik siswa kelas VIII A antara lain: 1) adanya siswa yang sudah mahir bermain musik tradisional. 2) tajamnya kesenjangan kemampuan musikal sebagian besar siswa yang berdampak rendahnya prestasi belajar seni musik.

PTK akan dilaksanakan di SMP Negeri 1 Sukaresmi Jl. Mariwati Km. 8 SukaresmiCianjur, Telp (0263) 581874.

Instrumen pengumpulan data yang di perlukan dalam penelitian ini diperoleh dari

1. Tes praktek ini digunakan untuk memperoleh data mengenai kemampuan dan kreativitas siswa yang dilaksanakan setelah pembelajaran berlangsung.
Sedangkan metode yang digunakan adalah metode tutor sebaya untuk kreativitas memainkan musik tradisional.

2. Lembar observasi agar data dapat dianalisis dengan mudah, observasi dilakukan dengan menggunakan instrument observasi dan dilakukan oleh seorang guru yang berperan sebagai observer. Pada saat praktik memainkan musik siswa diklasifikasikan dalam 3 kategori:

a. Kurang, jika siswa pasif tidak berperan serta dalam proses pembelajaran musik.

b. Sedang/cukup, jika siswa berperan aktif dalam proses pembelajaran dan menanggapi bimbingan yang diberikan, tetapi kurang menjiwai dengan musik.

c. Baik, jika siswa berperan aktif dalam proses pembelajaran dan dapat menerapkan kemampuan bermusiknya.

Menurut Nasution yang menyatakan bahwa observasi merupakan pengamatan yang dilakukan untuk memperoleh informasi tentang perilaku anak sehari-hari. Dari hasil ini kita dapat memperoleh gambaran yang jelas tentang masalahnya dan mungkin petunjuk tentang cara memecahkannya (1996: 106). Proses observasi ini dilakukan selama kunjungan di lapangan dengan mengatasi situasi berbagai hal mengenai proses berjalannya latihan mempraktekan dari segi persiapan sampai selesainya proses latihan tersebut. Metode observasi pada penelitian ini digunakan untuk mengamati jalannya proses latihan praktek tari yang meliputi: lokasi atau Metode observasi atau pengamatan merupakan salah satu alat yang digunakan oleh peneliti untuk mengumpulkan data-data di lapangan. Menurut Sudjana metode observasi adalah metode yang menganalisa dan mengadakan pencatatan secara sistematis mengenai tingkah laku dengan melihat atau mengamati individu atau tempat dimana situasi yang menjadi objek penelitian berlangsung, person atau orang (perilaku) yang menjadi subjek yang diteliti, dalam hal ini adalah anak-anak yang mengalami kesulitan belajar, dan kegiatan dan aktivitas subjek yang diteliti. 
Model observasi yang dilakukan dalam penelitian ini adalah: observasi partisipasifyaitu observasi yang dilakukan dengan melibatkan diri di lapangan, observasi terus terang dan tersamar. Terus terang jika mereka yang diteliti mengetahui sedari awal, tersamar bila yang diteliti tak mengetahui sedang diobservasi dengan tujuan untuk memperoleh data yang valid, dan observasi tidak terstruktur yaitu observasi tersebut tidak terencana sebelumnya, sehingga fokus observasi dapat berkembang dari sini.

Penelitian tindakan kelas ini direncanakan 2 siklus. Tiap siklus dilaksanakan sesuai dengan rencana yang telah ditetapkan. Langkah awal yang dilakukan sebelum PTK dilaksanakan adalah melaksanakan Pre Test berupa praktik unjuk kerja kepada siswa untuk melihat kemampuan dan kreativitas bermusik siswa. Hasil tes siswa dianalisa untuk menentukan tindakan yang tepat dalam mengatasi kesulitan siswa menghubung-hubungkan fakta dan membuat kesimpulan. Dari hasil analisa maka ditetapkan bahwa tindakan yang digunakan untuk mengatasi rendahnya kemampuan dan kreativitas musikal siswa adalah melakukan pembiasaan praktik latihan bermain musik di akhir pembelajaran

Untuk melaksanakan pembelajaran dengan tutor sebaya, guru/peneliti mempersiapkan bahan ajar dan langkah-langkah mengajar sedemikian rupa sehingga mudah dipahami oleh tutor dan oleh peserta didik, seperti yang digambarkan pada bagan Riset Aksi Model John Elliot dibawah ini:

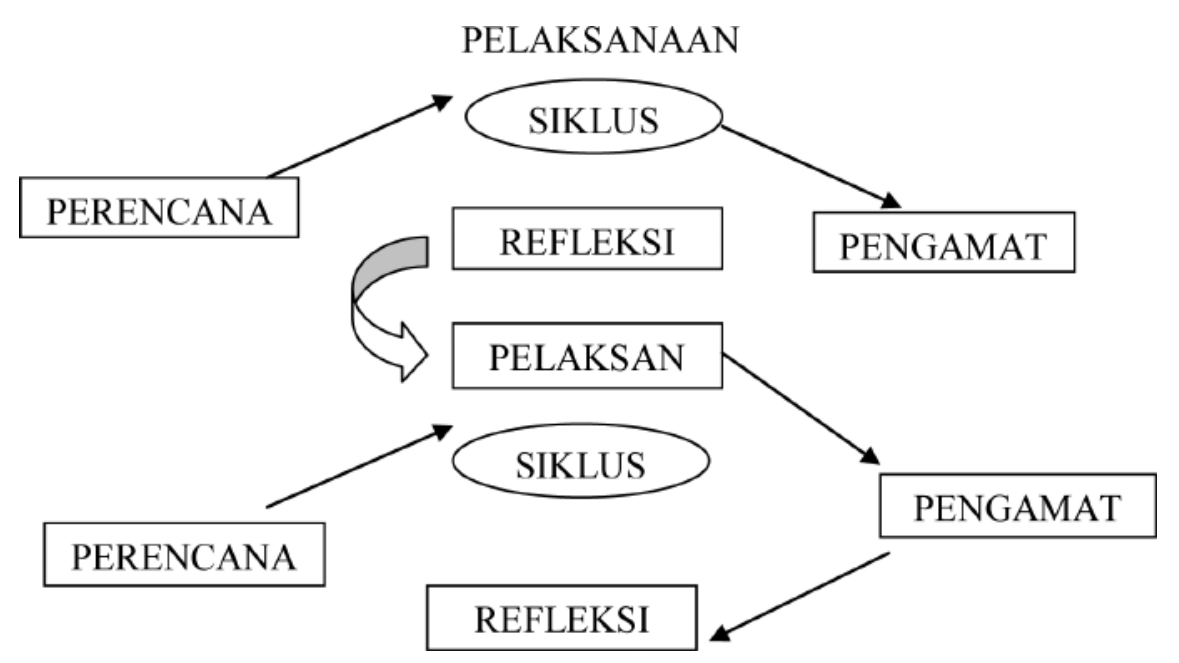

Bagan Riset Aksi Model John Elliot

\section{HASIL DAN PEMBAHASAN \\ Hasil}

Sebelum melaksanakan Penelitian Tindakan Kelas di kelas VIII A SMP N I Sukaresmi, peneliti lebih dulu melakukan pra penelitian, diantaranya merekap nilai aspek memainkan Musik Tradisional pada pembelajaran Seni Budaya. Dari nilai yang diperoleh, ternyata kemampuan dan kreativitas siswa dalam memainkan Musik Tradisional masih tergolong rendah. Berdasarkan hal tersebut, maka peneliti memutuskan untuk menerapkan teknik pembelajaran dengan menggunakan metode tutor sebaya untuk meningkatkan kemampuan dan kreativitas dalam memainkan musik tradisional.

Pembelajaran dilaksanakan dengan melaksanakan tes awal untuk mengetahui kemampuan awal siswa dalam kemampuan memainkan musik. Nilai tes awal dijadikan acuan untuk mengetahui hasil belajar siswa setelah menggunakan metode tutor sebaya. Tes awal berupa materi yang berhubungan dengan materi yang akan diajarkan. Berikut ini disajikan data hasil belajar siswa pada Pra Siklus: 
Tabel 1. Data Hasil Belajar Siswa pada Pra Siklus

\begin{tabular}{clcc}
\hline No & \multicolumn{1}{c}{ Nama } & Nilai & Ketuntasan \\
\hline 1 & Jumlah nilai di & $>75$ & 14 orang \\
& atas KKM & & \\
2 & Jumlah nilai di & $<75$ & 24 orang \\
& bawah KKM & & \\
3 & Rata-rata & 72,03 & \\
4 & Nilai Tertinggi & 80 & \\
5 & Nilai Terendah & 64 & \\
6 & Ketuntasan & $36,84 \%$ & \\
\hline
\end{tabular}

Jika digambar dalam bentuk grafik, maka data hasil belajar siswa pada Pra Siklus dapat dilihat pada grafik dibawah ini.

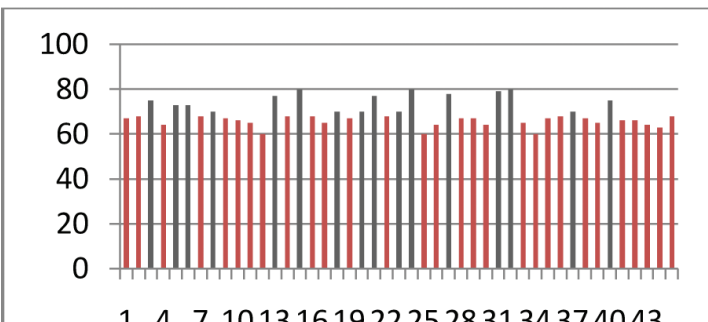

147101316192225283134374043

Grafik 1.

Data Hasil Belajar pada Pra Siklus

Dari hasil penelitian sebelum dilakukan penelitian, dapat dilihat adanya nilai dibawah KKM dalam pembelajaran Seni Budaya. Nilai tertinggi yang diperoleh siswa adalah 80,00 , sedangkan yang terendah adalah 64,00. Jumlah siswa yang telah mencapai KKM ada 14 siswa atau $36,84 \%$, sedangkan yang belum mencapai KKM ada 28 siswa atau $63,16 \%$.

Nilai KKM yang telah di tetapkan yaitu 77,00 . Dengan demikian dapat disimpulkan bahwa nilai Seni Budaya khususnya seni musik yang diperoleh siswa tergolong rendah. Oleh karena itu perlu kiranya peneliti mengadakan perubahan dengan melaksanakan tindakan pembelajaran, salah satu dianataranya adalah dengan menggunakan Metode Tutor Sebayal ini. Dengan metode ini diharapkan siswa mampu menguasai musik tradisional, sehingga mampu menerapkannya dalam kreativitas bermusik.

\section{Tindakan Siklus 1}

Tindakan siklus 1 dilaksanakan dalam 2 kali pertemuan, yaitu pada hari Selasa, 7 Oktober 2014 dan Selasa, 14 Oktober 2014

a. Perencanaan Tindakan

- Melakukan identifikasi masalah dan merencanakan langkah-langkah yang akan dilaksanakan pada siklus 1 .

- Menyusun Rencana Pelaksanaan Pembelajaran (RPP).

- Menentukan pokok bahasan yang dijadikan materi pada penelitian.

- Mengembangan Rencana Pelaksanaan Pembelajaran (RPP).

- Mengembangkan format evaluasi.

- Mengembangkan format observasi pembelajaran.

b. Pelaksanaan Tindakan

1. Pelaksanaan pembelajaran pada pertemuan pertama

Hari/Tanggal: Selasa, 7 Oktober 2014

Waktu: Jam ke 1 - 2 (07.30 - 08.50)

- Guru memeriksa kesiapan siswa, mengecek absensi siswa dan mengondisikan kelas agar pembelajaran dapat berlangsung secara kondusif.

- Melakukan apersepsi dengan Tanya jawab tentang materi yang akan diajarkan.

- Siswa diminta untuk duduk dalam kelompok, tiap kelompok terdiri dari 6 orang.

- Siswa memperhatikan temannya yang sedang memainkan musik tradisional.

- Siswa berlatih memainkan musik tradisional secara berkelompok.

- Guru menutup pelajaran dengan membimbing siswa untuk menghapal dan berlatih secara rutin memainkan musik tradisional.

2. Pelaksanaan pembelajaran pada pertemuan ke dua.

Hari/Tanggal: Selasa, 14 Oktober 2014

Waktu: Jam ke 1 - $2(07.30-08.50)$ 
- Guru memeriksa kesiapan siswa, mengecek kehadiran siswa dan mengondisikan kelas agar pembelajaran belangsung dengan kondusif.

- Melakukan apersepsi (brainstorming) untuk pelajaran yang akan disampaikan.

- Siswa menyiapkan diri secara berkelompok untuk kembali berlatih mengulang memainkan musik tradisional yang telah diberikan sebelumnya.

- Siswa yang kemampuan bermainnya lebih baik membantu temannya yang masih kurang.

- Siswa bermain musik bergantian secara berkelompok.

- Guru menutup pelajaran dengan memberikan tugas menghafal dan berlatih musik tradisional

c. Observasi

Dari hasil observasi siklus 1, didapatkan bahwa guru telah menerapkan penggunaan metode tutor sebaya sesuai dengan Rencana Pelaksanaan Pembelajaran (RPP) yang telah disiapkan. Berdasarkan hasil pengamatan yang dilakukan observer, pada saat guru menjelaskan, masih ada siswa yang masih kurang memperhatikan.

Data mengenai keaktifan siswa dapat diperoleh dengan menggunakan lembar observasi. Keaktifan siswa tersebut dapat dilihat dalam hal menyimak dan menjawab pertanyaan secara lisan pada saat proses pembelajaran berlangsung. Data mengenai keaktifan siswa pada Siklus I dapat dilihat pada tabel 2.

Tabel 2. Rekapitulasi Keaktifan Siswa Pada Siklus I

\begin{tabular}{cccc}
\hline No & Keaktifan & Jumlah & $\%$ \\
\hline 1 & B & 11 & $24 \%$ \\
2 & C & 12 & $27 \%$ \\
3 & K & 22 & $49 \%$ \\
\hline
\end{tabular}

Jika digambar dalam bentuk grafik, maka rekapitulasi keaktifan siswa pada siklus I tersaji pada grafik berikut ini :

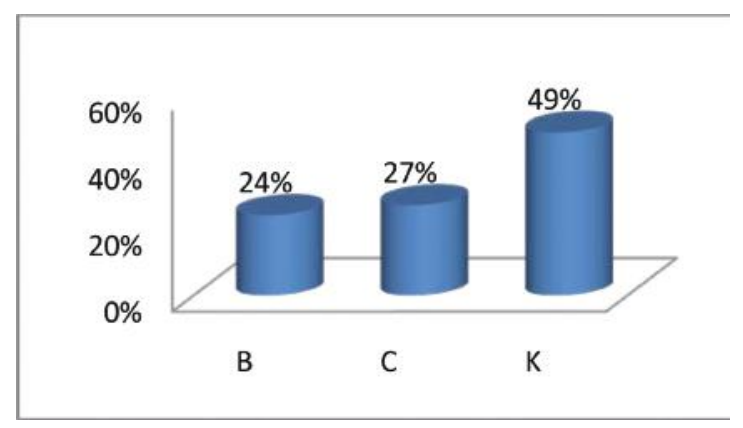

Grafik 2

Keaktifan Siswa Pada Siklus I

Data hasil pengamatan observer mengenai aktivitas guru pada Siklus I dapat dilihat pada tabel berikut ini.

\section{Hasil Pengamatan Aktivitas Guru Pada Siklus I}

Untuk mengetahui hasil belajar siswa, maka pada akhir Siklus I dilakukan tes hasil belajar yang dapat dilihat pada table dibawah ini :

Tabel 3. Daftar Hasil Belajar Siswa pada Siklus I

\begin{tabular}{clcc}
\hline No & \multicolumn{1}{c}{ Nama } & Nilai & Ketuntasan \\
\hline 1 & Jumlah nilai diatas & $>75$ & 25 orang \\
& KKM & & 13 orang \\
2 & Jumlah Nilai di & $<75$ & \\
& bawah KKM & & \\
3 & Rata-rata & 77,05 & \\
4 & Nilai Tertinggi & 83 & \\
5 & Nilai Terendah & 68 & \\
6 & Ketuntasan & $65,79 \%$ & \\
\hline
\end{tabular}

Jika digambar dalam bentuk grafik, maka data hasil belajar siswa pada siklus tersaji pada grafik 3 . 


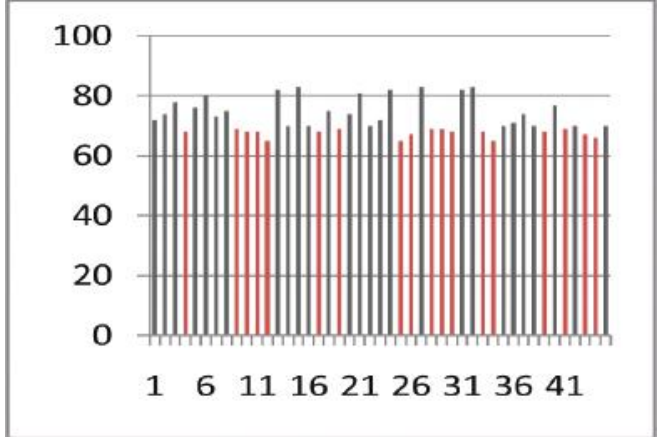

Grafik 3.

Data Hasil Belajar Siswa pada Siklus I

\section{d. Refleksi}

Berdasarkan analisis data di atas, masih terdapat kekurangan pada siklus I. Kekurangan tersebut diantara lain guru kurang memotivasi siswa dan memperhatikan siswa yang kurang aktif. Dengan adanya kekurangan tersebut, maka perlu adanya perbaikan dalam KBM pada siklus II. Selain memotivasi siswa, guru harus mengkondisikan siswa lebih baik sehingga siswa benar-benar terlibat dalam KBM.

3. Tindakan Siklus II

a. Perencanaan Tindakan

- Melakukan identifikasi masalah dan merencanakan langkah-langkah yang akan dilaksanakan pada silkus II.

- Melakukan identifikasi masalah dana merencanakan langkah-langkah yang akan dilaksanakan pada siklus II.

- Menyusun Rencana Pelaksanaan Pembelajaran (RPP).

- Menentukan pokok bahasan yang akan dijadikan materi bahasan pada penelitian.

- Mengembangkan Rencana Pelaksanaan Pembelajaran (RPP).

- Mengembangkan format evaluasi.

- Mengembangkan format observasi pembelajaran.

b. Pelaksanaan Tindakan

Pelaksanaan tindakan pada siklus II dilaksanakan dalam dua kali pertemuan yaitu pada hari Selasa, 21 Oktober 2014 dan Selasa, 28 Oktober 2014.
1. Pelaksanaan pembelajaran pada pertemuan pertama

Hari/ tanggal: Selasa, 21 Oktober 2014

Waktu: Jam ke $1-2(07.30-08.50)$

- Guru memeriksa kesiapan siswa, mengecek absensi siswa dan mengondisikan kelas agar pembelajaran dapat berlangsungsecara kondusif.

- Melakukan apersepsi dengan tanya jawab tentang materi yang akan dijalankan siswa berlatih memainkan musik tradisional bergantian secara berkelompok.

- Guru menutup pelajaran dengan membimbing siswa melakukan latihan dan pemberian tugas dari materi yang diajarkan.

2. Pelaksanaan pembelajaran pada pertemuan kedua

Hari/ tanggal: Selasa, 28 Oktober 2014

Waktu: Jam ke 1-2 (07.30 - 08.50)

- Guru memeriksa kesiapan siswa, mengecek absensi siswa dan mengondisiskan kelas agar pembelajaran dapat berlangsung secara kondusif.

- Melakukan apersepsi dengan tanya jawab tentang materi yang diajarkan.

- Siswa berlatih memainkan 1 buah lagu dengan menggunakan musik tradisional.

- Siswa menampilkan musik tradisional secara berkelompok

- Guru menutup pelajaran dengan melihat penampilan permainan musik siswa secara berkelompok.

Tabel 4. Rekapitulasi Keaktifan Siswa Pada Siklus II

\begin{tabular}{cccc}
\hline No & Keaktifan & Jumlah & $\%$ \\
\hline 1 & $\mathrm{~B}$ & 32 & $71 \%$ \\
2 & $\mathrm{C}$ & 13 & $29 \%$ \\
3 & $\mathrm{~K}$ & 0 & 0 \\
\hline
\end{tabular}


Jika digambar dalam bentuk grafik, maka rekapitulasi keaktifan siswa pada siklus II tersaji pada grafik berikut ini :

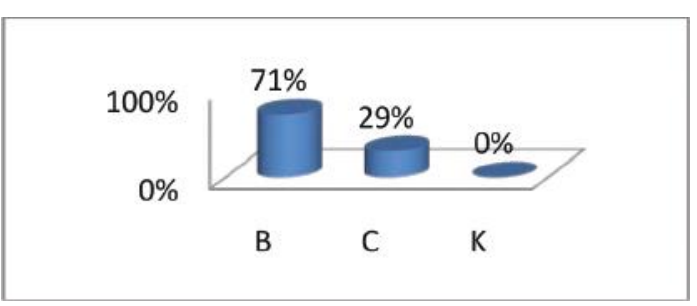

Grafik 4

Keaktifan Siswa Pada Siklus II

Hasil pengamatan mengenai aktivitas guru pada Siklus II dapat dilihat pada tabel 4.9 berikut ini.

\section{Hasil Pengamatan Aktivitas Guru Pada Siklus II}

Data hasil belajar siswa yang direkap dari hasil tes siswa pada Siklus II dapat dilihat pada tabel 5 berikut ini.

Tabel 5. Data Hasil Belajar Siswa pada Siklus II

\begin{tabular}{clcc}
\hline No & \multicolumn{1}{c}{ Nama } & Nilai & Ketuntasan \\
\hline 1 & Jumlah nilai di & $>75$ & 38 orang \\
& atas KKM & & \\
2 & Jumlah Nilai di & $<75$ & \\
& bawah KKM & & \\
3 & Rata-rata & 80,55 & \\
4 & Nilai Tertinggi & 86 & \\
5 & Nilai Terendah & 77 & \\
6 & Ketunuasan & $100 \%$ & \\
\hline
\end{tabular}

Jika digambarkan dalam bentuk grafik, maka data hasil belajar siswa pada Siklus II tersaji pada grafik 5 berikut ini:

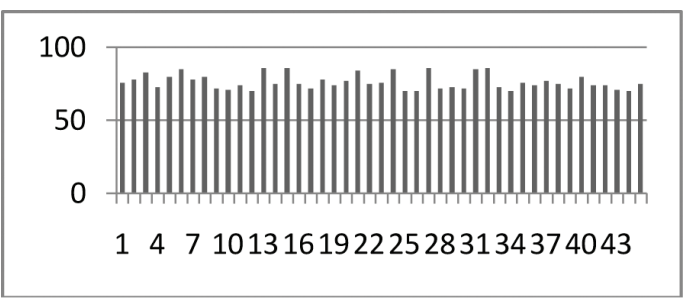

Grafik 5

Data Hasil Belajar Siswa pada Siklus II
Refleksi

Dengan analisis data diatas, terlihat adanya peningkatan minat siswa karena adanya motivasi dari guru dan karena siswa menyukai pembelajaran dengan penggunaan metode tutor sebaya ini. Hasil penilaian yang diperoleh siswa selama penelitian menunjukan adanya peningkatan baik dalam kerja kelompok maupun secara individual.

\section{Pembahasan}

Dari hasil pembelajaran dengan menggunakan metode tutor sebaya ini, dapat diketahui adanya peningkatan baik dari nilai kemampuan maupun kreativitas siswa dalam memainkan musik tradisional. Berikut ini adalah data yang diperoleh siswa pada Pra Siklus, Siklus I dan Siklus II.

Tabel 7. Rekapitulasi Nilai Rara-rata Hasil Evaluasi

\begin{tabular}{clc}
\hline No & \multicolumn{1}{c}{ Nama } & Nilai Rata-rata \\
\hline 1 & Pra Siklus & 72,03 \\
2 & Siklus I & 77, \\
3 & Siklus II & 78,40 \\
\hline
\end{tabular}

Data peningkatan nilai rata-rata hasil evaluasi siswa pada Pra Siklus, Siklus I dan Siklus II dapat dilihat pada tabel 6.

\section{Rekapitulasi Nilai Rata-rata Hasil Evaluasi}

Peningkatan rata-rata nilai siswa ditunjang pula oleh peningkatan nilai terendah dan nilai tertinggi yang diperoleh siswa pada setiap siklus seperti yang tertera pada tabel 8 .

Tabel 8. Rekapitulasi Nilai Tertinggi dan Nilai Terendah

\begin{tabular}{clcc}
\hline No & Kegiatan & $\begin{array}{c}\text { Nilai } \\
\text { Terendah }\end{array}$ & $\begin{array}{c}\text { Nilai } \\
\text { Tertinggi }\end{array}$ \\
\hline 1 & Pra Siklus & 60 & 80 \\
2 & Siklus I & 65 & 83 \\
3 & Siklus II & 70 & 86 \\
\hline
\end{tabular}

Data peningkatan rata-rata Nilai Tertinggi dan Nilai Terendah dapat dilihat pada grafik 4.9 berikut ini: 
Tabel 6. Rekapitulasi Nilai Pra Siklus, Siklus I dan Siklus II

\begin{tabular}{clccc}
\hline No & \multicolumn{1}{c}{ Nama } & Pra Siklus & Siklus I & Siklus II \\
\hline 1 & Agus Lukman Hidayatulloh & 78 & 80 & 82 \\
2 & Ahmad Ridwan Fauzie & 68 & 77 & 78 \\
3 & Alisa Ashadiah Meyliana & 77 & 78 & 83 \\
4 & Andin Fauziah & 70 & 74 & 78 \\
5 & Bayu Syaripudin & 75 & 77 & 80 \\
6 & Christien Octaviani & 70 & 80 & 85 \\
7 & Dadang Maulan & 74 & 78 & 80 \\
8 & Deden Supriatna & 77 & 79 & 80 \\
9 & Deni Hamdani & 67 & 73 & 77 \\
10 & Dewi Ramadhani & 70 & 74 & 78 \\
11 & Dina Sri Cahyanti & 65 & 68 & 77 \\
12 & Ega Yuda Mandala Putra & 66 & 70 & 77 \\
13 & Emal Salina & 77 & 82 & 86 \\
14 & Fachita Lutfia Zalpa & 80 & 83 & 86 \\
15 & Heru Permana & 68 & 79 & 80 \\
16 & Ismi Lathipah & 68 & 77 & 79 \\
17 & Junaedi & 65 & 70 & 78 \\
18 & Kartika Rahmah & 78 & 80 & 82 \\
19 & Krisdianti & 67 & 72 & 78 \\
20 & Lusi Aprliyanti & 75 & 78 & 80 \\
21 & Melenia & 77 & 81 & 84 \\
22 & Mirahmawati & 68 & 78 & 80 \\
23 & Moch Sahid Abdilah & 76 & 80 & 81 \\
24 & Muhamad Ilyas & 80 & 82 & 85 \\
25 & Muhamad Rafli Yasin & 70 & 75 & 79 \\
26 & Muhamad Rizki & 68 & 74 & 78 \\
27 & Muhamad Tisna & 78 & 83 & 86 \\
28 & Muhamad Tedi Mulyadi & 77 & 79 & 81 \\
29 & Nurfazilah Tiana P & 67 & 75 & 78 \\
30 & Ridwan Maulana & 66 & 70 & 77 \\
31 & Saepul & 79 & 82 & 85 \\
32 & Septia Anggraeni & 80 & 83 & 86 \\
33 & Siti Fatimah Diani & 65 & 70 & 77 \\
34 & Siti Nurmeilani & 68 & 74 & 78 \\
35 & Susilawati & 67 & 77 & 80 \\
36 & Suwandi Saputra & 68 & 78 & 80 \\
37 & Teti Ariyanti & 67 & 79 & 80 \\
38 & Adisti Sartika & 79,03 & 77,05 & 80,55 \\
\hline & Rata-rata & 80 & 83 & 86 \\
\hline & Nilai Tertinggi & 68 & $65,79 \%$ & $100 \%$ \\
\hline & Nilai Terendah & & & \\
\hline & Ketuntasan & 77 & 87 \\
\hline & & 67 & & \\
\hline
\end{tabular}

Tabel 10. Rekapitulasi Nilai Seni Budaya Berdasarkan Nilai KKM

\begin{tabular}{llcccc}
\hline \multirow{2}{*}{ No } & \multirow{2}{*}{ Kegiatan } & \multicolumn{2}{c}{ Tuntas } & \multicolumn{2}{c}{ Belum Tuntas } \\
\cline { 3 - 6 } & & Jumlah & $\%$ & Jumlah & $\%$ \\
\hline 1 & Pra Tindakan & 16 & $35,56 \%$ & 29 & $64,44 \%$ \\
2 & Siklus I & 27 & $60 \%$ & 18 & $40 \%$ \\
3 & Siklus II & 43 & $100 \%$ & - & - \\
\hline
\end{tabular}




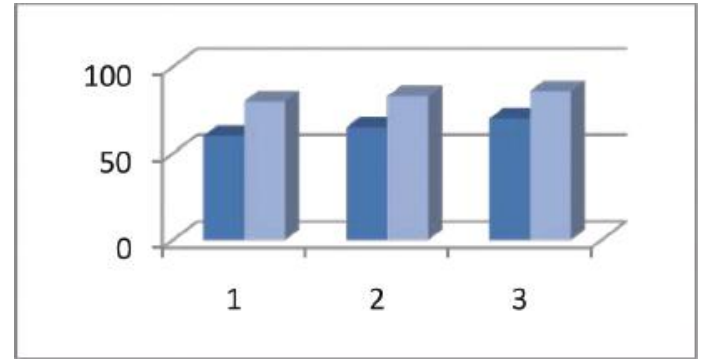

Grafik 9.

Data Peningkatan Nilai Terendah dan Tertinggi pada Setiap Siklus

Dari grafik 9 diatas diperoleh bahwa nilai terendah yang diperoleh siswa pada Pra Siklus adalah 60, kemudian meningkat menjadi 65 pada Siklus I dan meningkat lagi menjadi 70 pada Siklus II. Demikian pula nilai tertinggi yang diperoleh siswa pada Pra Siklus II adalah 80 , meningkat mejadi 83 pada Siklus I dan pada Siklus II menjadi 86. Hal ini menandakan bahwa penggunaan metode demontrasi dapat diterapkan untuk meningkatkan kemampuan dan keterampilan dalam praktik tari tradisional. Selain peningkatan rata-rata nilai siswa, penggunaan metode demontrasi juga dapat pula meningkatkan presentase ketuntasan belajar siswa, seperti tersaji pada tabel 10 .

Data peningkatan rata-rata nilai hasil belajar siswa pada Pra Siklus, Siklus I dan Siklus II berdasarkan nilai KKM dapat dilihat dari grafik 11 berikut ini.

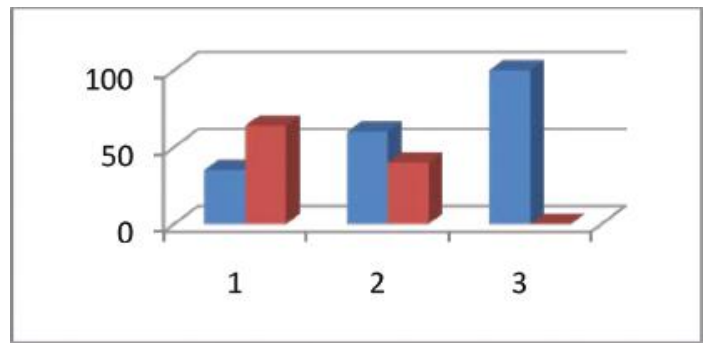

Grafik 11.

Presentase Peningkatan Nilai Seni Budaya Berdasarkan Nilai KKM

\section{KESIMPULAN}

Berdasarkan hail penelitian yang telah dilakukan di Kelas VIII A SMPN 1 Sukaresmi, diambil keputusan sebagai berikut:
1. Peningkatan kemampuan dalam kreativitas siswa dalam memainkan musik tradisional di SMPN 1 Sukaresmi ini, dapat dilihat dari hasil penilaian yang dilakukan pada kegiatan Siklus I dan Siklus I. Prestasi belajar siswa melalui penilain proses kerja kelompok dan tes individual pada siklus I dan siklus II meningkat. Penggunaan metode tutor sebaya ini adalah suatu cara untuk menarik minat siswa untuk mempelajari kreativitas memainkan musik tradisional karena disajikan dalam berbagai tayangan yang menarik, penggunaan metode tutor sebaya dalam Seni Budaya ini baik sekali untuk diterapkan dalam pembelajaran kreativitas memainkan musik tradisional khususnya, dan juga untuk keterampilan yang lainnya yaitu seni tari, seni rupa atau teater sehingga siswa dapat mengembangkan dalam lingkungan kehidupan sehari-hari.

2. Pada Pra Penelitian, siswa yang belum mencapai nilai KKM ada 24 orang $(63,16 \%)$, pada siklus I berkurang menjadi 13 orang $(34,21 \%)$ berarti naik sekitar $25 \%$ dari sebelumnya, dan setelah pelaksanaan tindakan kelas pada siklus II seluruh siswa yaitu 38 orang (100\%) mencapai nilai KKM $(77,00)$ Nilai rata-rata yang diperoleh siswa adalah 72,03 pada Pra Siklus, 77,05 pada siklus I dan pada Siklus II 80,55. Dengan demikian dapat dilihat adanya peningkatan dari nilai sebelum penelitian.

3. Dari data keaktifan siswa pada siklus I hanya 11 orang (34\%) yang keaktifannya baik, pada siklus II menjadi 32 orang (71\%) terdapat peningkatan sekitar $47 \%$, pada siklus I siswa yang cukup aktif dari 12 orang (27\%) menjadi 13 orang (29\%) pada siklus II dan yang kurang aktif pada siklus I ada 22 orang (49\%) pada siklus II sudah tidak ditemukan lagi siswa yang kurang aktif.

4. Sedangkan pada data aktivitas guru dari 17 komponen yang ada pada siklus I ada 5 komponen (29\%) aktivitas guru yang nilainya baik kemudian menjadi 15 komponen (88\%) pada siklus II, pada 
siklus I ada 9 komponen (53\%) sedangkan pada siklus II tinggal 2 komponen (12\%) aktivitas guru yang nilainya cukup dan aktivitas guru yang kurang pada siklus I ada 3 komponen (18\%) sedangkan pada siklus II tidak ditemukan lagi aktivitas guru yang nilainya kurang.

5. Peningkatan selain dari data kuantitatif dan kualitatif, juga berdasarkan Angket Respons siswa yang menyatakan hampir $90 \%$ siswa merasa senang dengan penggunaan metode tutor sebaya ini, walaupun ada beberapa hambatan seperti pada pengoperasian alat-alat tersebut, namun demikian hampir seluruh siswa termotivasi dalam pembelajaran ini.

\section{DAFTAR PUSTAKA}

Muslihudin. (2010). Kiat Sukses Melakukan Penelitian Tindakan Kelas dan Sekolah. Bandung. Rizkkqi Press.

Surya, Moch. (1995). Psikologi Pendidikan. Bandung. Jurusan PPB UPI

Tim Redaksi. (1997). Kamus Bahasa Indonesia. Jakarta. Pusat Bahasa.

Purnomo, Wahyu. (2010). Terampil Bermusik untuk SMP dan MTs. Jakarta. Kementerian Pendidkan Nasional

Sagala, Syaiful. (2009). Konsep dan Makna Pembelajaran untuk Membantu Problematika Belajar dan Mengajar. Bandung. Alfabeta.

Wiriaatmadja, Rochiati. (2009). Metode Peneltian Tindakan Kelas. Bandung, Remaja Rosdakarya Offset. 